challenge of numerous "diabolical mixtures ... aroused my combative instincts, and provided real excitement . . . Gradually the classics were supplanted by a new enthusiasm. Then followed a truly decisive event. Professor Charles R. Sanger told me that next year's class would be larger than usual. Would I serve as assistant without stipend? Of course I said 'Yes,' and so, not long after my eighteenth birthday, I became a duly appointed officer of instruction in Harvard University, continuing on through senior year . . . Ten years later, this adventure had a direct influence on my fortunes. When Professor Sanger's health became impaired, I was asked to collaborate with him. Upon his death, I took charge of qualitative analysis, and thus my feet became planted upon the academic ladder."

By that time Forbes had long since passed from undergraduate to graduate work at Harvard. Under the direction of T.W. Richards, later to become America's first Nobel laureate in the sciences, Forbes completed in 1905 a doctoral thesis on the electrochemistry of amalgams. He then went on with Richards to a revision of the atomic weights of nitrogen and silver. The keystone of this endeavour was a meticulous redetermination of the exact weight of pure silver nitrate yielded by one gram of pure silver, and the result thus obtained still stands unchallenged (good to $0.002 \%$ ). But this notable first was also Forbes' last investigation of atomic weights. Most of his nearly 100 research publications deal with solution physical chemistry, especially electrochemistry, and with photochemistry, in which field he was an American pioneer.

Forbes' life and career were wholly centered on Boston and Cambridge Massachusetts. To be sure, he spent 1906-07 at the universities of Leipzig and Berlin, followed by two years as associate in chemistry at Bryn Mawr College. But in 1909 he returned as instructor in physical chemistry to Harvard University, and here he stayed to become Professor in 1926, Chairman of the Chemistry Department in the difficult years 1944-47, and Emeritus Professor in 1948. Even then Forbes' academic career continued for 8 years more Northeastern University and, still persevering as a consultant to chemical industry, inuing as a consultant to chemical industry, he continued laboratory work with his own hands until the age of 90 . Triumphant over the hazards besetting the experimental chemist, he was at 97 the oldest living graduate of Roxbury Latin. He outlived his cherished wife of 60 years, née Marie Louise Hersey, but is survived by a son, a daughter, and four grandchildren.

Born into a family where father, mother (née Elizabeth Shannon), aunts, and uncles were all teachers, Forbes came naturally to that vocation. His teaching career spanned 60 years and some 9000 students. A highlyorganized lecturer who wrote everything out in a well-ordered display on the black- board, Forbes was also a willing spontaneous commentator on the illuminating aberrations of the innumerable lecture experiments he dextrously produced. He was in 1951 the deservedly first recipient of the James Flack Norris Award for outstanding achievement in the teaching of chemistry.

Forbes was a New Englander through and through: sturdy, spare, independent, reserved, and patient. But beneath the somewhat austere exterior lay abundant dry wit, and a human warmth that engaged many friends. An attractively multidimensional person, Forbes was a photographer of professional competence, an energetic hiker and climber (long the faculty adviser of the Harvard Mountaineering Club), and an avid musician who lent his (double bass) voice to many local choruses. His high sense of responsibility found expression in a lifetime of devoted service to his science, his Department, his University, and his Church. His was a New England life of little showiness but admirable substance.

Leonard K. Nash

\section{Sir Frank Fraser Darling}

THE death of Sir Frank Fraser Darling on 22 October 1979 at the age of 76 will be greatly regretted by naturalists and wildlife conservationists in many parts of the world. Although he only came to wide public notice in Britain when he gave the 1969 Reith Lectures, he had made outstanding contributions to the understanding of wild animals and of the countryside over a period of some 50 years, and his counsels were much sought after in America and elsewhere in the 1950s and ' 60 s, when his own countrymen paid less attention to his opinions.

He started work in 1924 as an agriculturalist. After three years on the staff of the Buckinghamshire County Council he went as a research student to the Institute of Animal Genetics in the University of Edinburgh. He was appointed Chief Officer of the Imperial Bureau of Animal Genetics in Edinburgh in 1930, under the late Professor F.A.E. Crew, and he remained in that post until 1933. He then gave up this urban, academic life, and began his work, often under conditions of considerable austerity, in the highlands and islands of Scotland. He held Carnegie and Rockefeller research fellowships, and was Director of the West Highland Survey from 1944-50, but this was a precarious existence with little of the security scientific workers expect today. However, he was able to spend his time in the field really getting to understand the conditions of his harsh environment.

During this period he wrote many books such as $A$ Herd of Red Deer and $A$ Naturalist on Rona, vividly describing his observations and his experience. His Bird Flocks and the Breeding Cycle initiated a new field of research. These books had a considerable appeal to other naturalists and to discerning scientists, but were dismissed as too "popular" by the educational establishment, and so did not receive the recognition his admirers felt they deserved. He was bitterly disappointed at the reception given by "the authorities" to his West Highland Survey. His apparently eccentric behaviour and unconventional way of life (something which would be thought normal today) also prevented him from being properly appreciated as an observer and an ecologist in academic circles. At a time when laboratory studies of animal cells or isolated organs were considered more scientific than those involving whole animals in the wild, and when even meticulous observation was considered inferior to experimentation, it is not surprising tht he felt he was not properly appreciated.

He did return to academic life for a few years when he was appointed Senior Lecturer in Ecology and Conservation at Edinburgh University in 1953 at the age of nearly 50 . He was also invited by the Nature Conservancy in Britain, then a young and developing organisation, to advise them in their studies on Red Deer. This work, and his earlier observations, enabled the Conservancy to introduce a proper management policy particularly to the island of Rhum, where within the National Nature Reserve populations of deer were maintained at optimum levels by a careful culling policy. However, Fraser Darling increasingly found tht his views were being taken more seriously in the United States of America, and in 1959 he accepted an invitation from Dr Fairfield Osborn to become Vice President of the Conservation Foundation in Washington DC. His studies of the caribou in Alaska with Dr Starker Leopold, and of the larger mammals in Norther Rhodesia and other African territories did much to consolidate his international reputation.

While in the United States he was impressed with the work done there in setting up National Parks, and he was critical of other countries, including his own, for their slowness in following the American example. However, he praised the British Nature Conservancy for their work, with limited resources, and particularly for establishing several valuable reserves in Scotland.

As already indicated, it was not until 1969 that Britain recognised his contribution to conservation. 1970 had been designated European Conservation Year, and plans to that end were being made by a committee under the patronage of HRH Prince Philip. It was suggested that the 1969 Reith Lectures of the British Broadcasting Corporation should be devoted to some suitable ecological topic, and that they should act as a curtain raiser. 
Fraser Darling was an inspired choice as the speaker. He took as his title Wilderness and Plenty. The lectures came at the right time, and the lecturer made the most of his opportunity. The public, as distinct from the scientific community, had just learned to use the word "ecology", and to be worried about the future of the environment. The impact of the lectures was considerable, and Fraser Darling was accepted, particularly by students, as a prophet. His status was also radically changed and, somewhat to his surprise, he found himself very much a part of the Establishment. The Queen honoured him with a knighthood, and he was in demand to join the most prestigious Quangos.

Thus from 1970 to 1973 he served on the Nature Conservancy, and in 1970 he was one of the first selected for the Royal Commission on Environmental Pollution. However, he was not seduced by his acceptance by the authorities, and still continued to speak his mind on environmental problems. He was in great demand as a speaker and a writer, but unfortunately ill health prevented him, particularly in recent years, from playing an active part in public life.

It is difficult to assess Fraser Darling's contribution to science at this time. His books show his deep but unsentimental feeling for the countryside and for the animals which inhabit it. He was able to communicate to the public (as in the Reith Lectures), and although this very ability aroused disapproval in some (? envious) academics, it enabled him to make a unique contribution to conservation. However, many of his colleagues, even those who admired him most, did not consider him to be an outstanding ecologist in the academic tradition, and it is not difficult to pick holes in some of his work. Nevertheless he was a leading figure who followed in the British tradition of the study of scientific natural history, and we can take comfort from the fact that at least for the last years of his life this was realised by his countrymen.

Kenneth Mellanby

\section{C.S. Hallpike}

Dr Charles Skinner Hallpike, CBE, FRS, FRCS, FRCP, who died on 26 September 1979 , aged 79 , was a neurootologist of international renown. He was the pioneer in that field and is respected as such in every country of the world.

Although an experienced physiologist and pathologist, Dr Hallpike's special interest was in the relationship of experimental observation to clinical problems. His ability for meticulous work and great clarity of thought enabled him to marshal facts and produce scientific papers in stylish and fluent prose. $\mathrm{He}$ is best remembered for his original description of the pathology of Ménière's disease and for the development of a caloric test technique which has, over the years, withstood the test of time and is now universally accepted.

Dr Hallpike was educated at St Paul's School and graduated in medicine at Guy's Hospital, London in 1926 where he was Entrance Scholar in Arts and Beaney Prizeman in Pathology. His interest in the ear began when he was House Surgeon to the aural departments of Guy's Hospital and Cheltenham General Hospital from 1924 to 1927. Thereafter, as Bernard Baron Research Fellow at the Ferens Institute of Otology, Middlesex Hospital, the publication of a number of papers concerned with the electrophysiology of hearing resulted in his being awarded the Duveen Travelling Studentship, University of London, 1930 and the Rockefeller Travelling Fellowship 1931, when he studied with Witmarck in Germany and in the University of Philadelphia, USA. His high standard of scholarship received further recognition in the awards of the Foulerton Gift Research Fellowship, Royal Society (1937-40) and Gamble Prize in 1934, William J. Muckle Fellowship, University of London, 1941 and Dalby Prize, 1943.

In 1942 he joined the scientific staff of the Medical Research Council at the National Hospital, Queen Square, London where his power of organisation and administration resulted in his appointment as Aural Physician and Director of a newly established Otological Research Unit at the hospital. Here, with his awareness of the close liason which should exist between laboratory and clinic in the solution of problems throughout the field of otology, his work became directed towards establishing this link to the great advantage of both. In association with experts in numerous allied disciplines including physics, physiology, biochemistry, histology and clinical investigation, a series of classic publications issued from his unit emphasising the importance of the adoption of quantitative methods in both laboratory and clinical studies of the ear.

The practical outcome of this work included the Medresco hearing aid, the peep-show technique for measuring deafness in young children, recognition of the diagnostic significance of loudness recruitment in sensori-neural deafness and the definition of a number of clinical and pathological entities hitherto grouped together as 'aural vertigo.' An improved technique for temporal bone microtomy was developed, a rotating chair, a head lamp for aural surgery and an ear microscope. Further studies contributed to knowledge of the heredity of labyrinthine disease and the biochemistry of the labyrinthine fluids. At a later stage the narrow-band masking technique for bone conduction audiometry was evolved and an electro-nystagmographic technique, the diagnostic significance of which is still increasing.

Dr Hailpike's unit gained international recognition in the awards he received of the
Gamble Prize for the second time and the Hughlings' Jackson Lectureship and Medal, Royal Society of Medicne 1947; Bárány Medal, University of Uppsala 1958; Guyot Medal, University of Groningen 1959 and the Dalby Prize (awarded jointly) in 1958. In 1956 he became a Fellow of the Royal Society and in 1958 he was honoured with a CBE.

Upon his retirement from the staff of the Medical Research Council, Dr Hallpike was appointed Honorary Aural Physician and Director of Research at the Ferens' Institute of Otolaryngology, Middlesex Hospital from 1965 to 1968 . He was a member of numerous learned societies including the Collegium Otorhinolaryngologicum Amicitiae Sacrum whose Shambaugh Prize was awarded to him in 1955. He was an Honorary Fellow of the Royal Academy of Medicine of Ireland, a Fellow of the Royal Society of Medine, being Honorary Secretary 1938, Editorial Representative 1946 to 1952 and Honorary Member of the Section of Otology 1970 . He was joint Founder of the Bárány Society in 1960, a society which now has world-wide membership and is unique as being solely directed to the study of vestibular problems. Between 1938 and 1965 he was a member of the Flying Personnel Research Committee where his almost unique knowledge of the ear's functioning in health and disease played a large part in overcoming aural problems important in aviation.

Dr Hallpike had the great merit of having inspired many collaborators to engage in scientific work and his wisdom and shrewd judgement will be remembered the world cover. He was the acknowledged master of his subject, albeit a hard one, a perfectionist, utterly singleminded in all he undertook. He was quick to recognise and appreciate good work, intolerant of fools but unfailing in giving due credit to his co-workers. The fact that the majority of his unit staff remained with him over the years, a number from its inception until his retirement, is testimony in itself to his integrity. He had enormous courage in the face of an orthopaedic disability resulting from a childhood injury which precluded many outside activities. He played billiards in his younger days and enjoyed rifle practice at Bisley for which he gained a number of awards. He played the piano and violin and was fond of classical music. He enjoyed gardening after his retirement and won prizes locally for his roses. He was a devoted family man and is survived by his wife, Barbara, and two sons.

His death is a great loss to British otology. The establishment of the Medical Research Council Hearing and Balance Unit at the National Hospital, Queen Square, under the directorship of Dr J.D. Hood, with other members of his old staff, remains a living tribute to his pioneer work. M.R. Dix 